\title{
Cyclopentadienyl dithiocarbamate and dithiophosphate molybdenum and tungsten complexes
}

\author{
Mikhail V. Galakhov a, Pilar Gómez-Sal a, Teresa Pedraz a, Maria Angela Pellinghelli b, \\ Pascual Royo ${ }^{\mathrm{a}, *}$, Antonio Tiripicchio ${ }^{\mathrm{b}}$, Amelio Vázquez de Miguel ${ }^{\mathrm{a}}$ \\ a Departamento de Química Inorgánica, Universidad de Alcalá de Henares, Campus Universitario, E-28871 Alcalá de Henares, Spain \\ ${ }^{\mathrm{b}}$ Dipartimento di Chimica Generale ed Inorganica, Chimica Analitica, Chimica Fisica, Università di Parma, \\ Centro di Studio per la Strutturistica Diffrattometrica del C.N.R., viale delle Scienze 78, I-43100 Parma, Italy
}

Received 12 October 1998

\begin{abstract}
Reactions of $\left[\mathrm{MCp}^{*} \mathrm{Cl}_{4}\right]\left(\mathrm{M}=\mathrm{Mo}, \mathrm{W} ; \mathrm{Cp}^{*}=\eta^{5}-\mathrm{C}_{5} \mathrm{Me}_{5}\right)$ with salts of the $N, N$-diethyldithiocarbamate $\left[\mathrm{Et}_{2} \mathrm{dtc}\right]^{-}$and $O, O^{\prime}$-diethyldithiophosphate $\left[\mathrm{Et}_{2} \mathrm{dtp}\right]^{-}$anions yield the paramagnetic metal(V) complexes $\left[\mathrm{MCp}^{*} \mathrm{Cl}_{3}\left(\mathrm{Et}_{2} \mathrm{dtc}\right)\right](\mathrm{M}=\mathrm{Mo}$, W) and $\left[\mathrm{MCp}^{*} \mathrm{Cl}_{3}\left(\mathrm{Et}_{2} \mathrm{dtp}\right)\right](\mathrm{M}=\mathrm{Mo}, \mathrm{W})$, respectively. Hydrolytic oxidation of both dithiocarbamate-molybdenum complexes with aqueous hydrogen peroxide leads to $\eta^{2}$-coordinated peroxo compounds $[\mathrm{MoCp} * \mathrm{Cl}(\mathrm{O}-\mathrm{O}) \mathrm{O}]$, which were also obtained from $\left[\mathrm{MoCp}^{*} \mathrm{Cl}_{4}\right]$. The related complexes $\left[\mathrm{MCp}{ }^{\prime} \mathrm{Cl}(\mathrm{O}-\mathrm{O}) \mathrm{O}\right]\left(\mathrm{M}=\mathrm{Mo}, \mathrm{Cp}^{\prime}=\eta^{5}-\mathrm{C}_{5} \mathrm{H}_{5} ; \mathrm{M}=\mathrm{W}, \mathrm{Cp}^{\prime}=\eta^{5}-\mathrm{C}_{5} \mathrm{Me}_{5}\right)$ were isolated in a similar way. Reduction of a THF solution of $\left[\mathrm{MoCp}^{*} \mathrm{Cl}_{4}\right]$ with one equivalent of $10 \% \mathrm{Na} / \mathrm{Hg}$ followed by the addition of one equivalent of ammonium dithiophosphate gives $\left[\mathrm{MoCp}^{*} \mathrm{Cl}_{2}\left(\mathrm{Et}_{2} \mathrm{dtp}\right)\right]$ which was also obtained via the reaction of [MoCp* $\left.\mathrm{Cl}_{3}\left(\mathrm{Et}_{2} \mathrm{dtp}\right)\right]$ with $\mathrm{MeMgCl}$, whereas reduction with three equivalents of $\mathrm{Na} / \mathrm{Hg}$ in the presence of $\mathrm{CN}^{t} \mathrm{Bu}$ leads to the molybdenum(II) complex [MoCp* $\left.\left(\mathrm{Et}_{2} \mathrm{dtp}\right)\left(\mathrm{CN}^{t} \mathrm{Bu}\right)_{2}\right]$ in high yield. All these compounds were characterized by elemental analysis, IR, ${ }^{1} \mathrm{H}$ - and ${ }^{13} \mathrm{C}$-NMR spectroscopy, magnetic susceptibility measurements and the molecular structures of $\left[\mathrm{Mo}\left(\eta^{5}-\mathrm{C}_{5} \mathrm{H}_{5}\right) \mathrm{Cl}\left(\mathrm{O}_{-}\right.\right.$ O)O] and $\left[\mathrm{Mo}\left(\eta^{5}-\mathrm{C}_{5} \mathrm{Me}_{5}\right) \mathrm{Cl}_{3}\left\{\eta^{2}-\mathrm{S}_{2} \mathrm{P}(\mathrm{OEt})_{2}\right\}\right]$ were determined by X-ray diffraction studies. (C) 1999 Elsevier Science S.A. All rights reserved.
\end{abstract}

Keywords: Cyclopentadienyl; Dithiocarbamate; Dithiophosphate; Molybdenum; Tungsten

\section{Introduction}

Dithiocarbamate and phosphate transition metal complexes have been extensively studied [1], although not many organometallic derivatives of the early transition metals have been reported. Sodium dithiocarbamates were used in metathetical reactions to prepare mono- and di-cyclopentadienyl Group 4-6 metal complexes [2]. In all of these compounds the carbamate ligand is usually bonded to the metal in a symmetrical chelate fashion. Related dithiophosphate complexes

\footnotetext{
* Corresponding author. Tel.: +34-1-88514765; fax: +34-18854683 .

E-mail address: proyo@inorg.alcala.es (P. Royo)
}

may also be prepared by similar metathetical reactions and transformations between monodentate and chelate coordination have been studied [3]. We have recently reported [4] the isolation of imido cyclopentadienylmolybdenum $(\mathrm{V})$ complexes by reaction of the tetrachloro derivatives with primary amines. Here we describe the preparation of dithiocarbamate and -phosphate molybdenum and tungsten( $\mathrm{V})$ complexes by metathesis of the tetrachloro derivatives and their reactions with hydrogen peroxide and reducing agents. The molecular structures of the dithiophosphate complex $\left[\mathrm{Mo}\left(\eta^{5}-\mathrm{C}_{5} \mathrm{Me}_{5}\right) \mathrm{Cl}_{3}\left\{\eta^{2}-\mathrm{S}_{2} \mathrm{P}(\mathrm{OEt})_{2}\right\}\right]$ and the peroxo derivative $\left[\mathrm{Mo}\left(\eta^{5}-\mathrm{C}_{5} \mathrm{H}_{5}\right) \mathrm{Cl}(\mathrm{O}-\mathrm{O}) \mathrm{O}\right]$ were determined by $\mathrm{X}$-ray diffraction studies. 


\section{Results and discussion}

\subsection{Synthesis of dithiocarbamate and-phosphate complexes}

Molybdenum and tungsten(V) dithiocarbamate complexes can easily be obtained by reacting the tetrahalides $\left[\mathrm{MCp}^{*} \mathrm{Cl}_{4}\right]\left(\mathrm{M}=\mathrm{Mo}, \mathrm{W} ; \mathrm{Cp}^{*}=\eta^{5}-\mathrm{C}_{5} \mathrm{Me}_{5}\right)$ with various salts of the $N, N$-diethyldithiocarbamate $\left[\mathrm{S}_{2} \mathrm{C}\left(\mathrm{NEt}_{2}\right)\right]^{-}$anion $\left(\left[\mathrm{Et}_{2} \mathrm{dtc}\right]^{-}\right)$. Reactions with the hydrated sodium salt $\mathrm{Na}\left[\mathrm{Et}_{2} \mathrm{dtc}\right] \cdot 2 \mathrm{H}_{2} \mathrm{O}$ gave low yields due to the immediate hydrolysis of the product with elimination of the free acid as shown in the IR spectra. Use of the anhydrous ammonium salt $\left(\mathrm{NH}_{4}\right)\left[\mathrm{Et}_{2} \mathrm{dtc}\right]$ provided a more convenient preparative method. Strictly anhydrous reaction conditions were maintained in order to prevent the formation of difficult to separate by-products. The most convenient reagent used was the silver salt $\mathrm{Ag}\left[\mathrm{Et}_{2} \mathrm{dtc}\right]$ which could be easily manipulated in its anhydrous form giving higher yields of pure products. We found that a $1 / 1$ mixture of dichloromethane and diethylether was the most suitable solvent system for this reaction since both the starting compounds and the target complexes were completely soluble and the insoluble silver chloride could easily be removed by filtration. Thus, the reaction of $\left[\mathrm{MCp}^{*} \mathrm{Cl}_{4}\right]$ with one equivalent of $\mathrm{Ag}$ [ $\left.\mathrm{Et}_{2} \mathrm{dtc}\right]$ was carried out in $\mathrm{CH}_{2} \mathrm{Cl}_{2} / \mathrm{Et}_{2} \mathrm{O}$ as shown in Scheme 1 to give the dithiocarbamate complexes $\left[\mathrm{MCp}^{*} \mathrm{Cl}_{3}\left(\mathrm{Et}_{2} \mathrm{dtc}\right)\right](\mathrm{M}=\mathrm{Mo} \mathbf{1}$, $\mathrm{W} 2$ ) in yields higher than $70 \%$ after purification.

Similar reactions carried out using the ammonium salt of the $O, O^{\prime}$-diethyldithiophosphate $\left[\mathrm{S}_{2} \mathrm{P}(\mathrm{OEt})_{2}\right]^{-}$ anion $\left(\left[\mathrm{Et}_{2} \mathrm{dtp}\right]^{-}\right)$gave the related dithiophosphate complexes $\left[\mathrm{MCp}^{*} \mathrm{Cl}_{3}\left(\mathrm{Et}_{2} \mathrm{dtp}\right)\right](\mathrm{M}=\mathrm{Mo} \mathrm{3,} \mathrm{W} \mathrm{4)}$. This is a more convenient reagent, more soluble than the silver salt using a $1 / 4 \mathrm{CH}_{2} \mathrm{Cl}_{2} / \mathrm{Et}_{2} \mathrm{O}$ mixture in which the

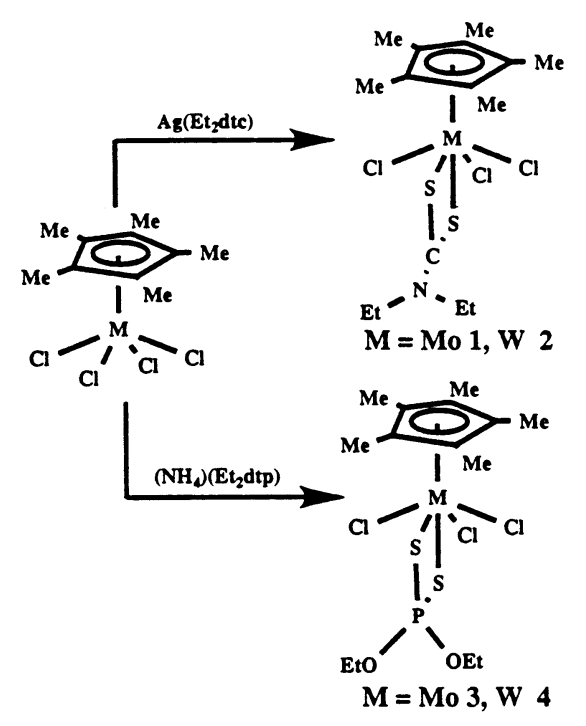

Scheme 1 .

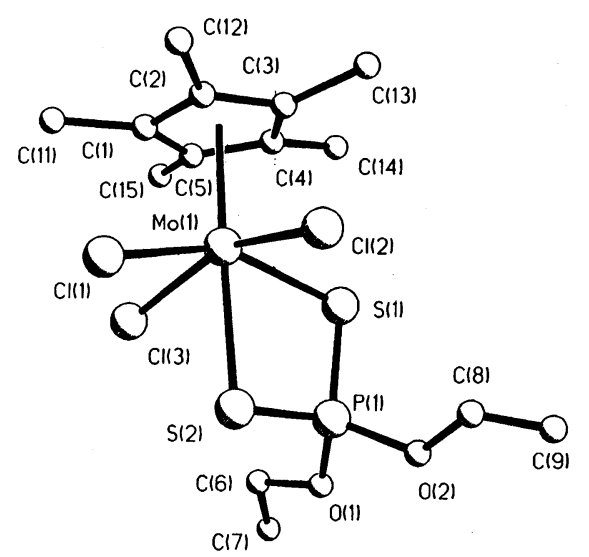

Fig. 1. View of the molecular structure of the compound $\left[\mathrm{Mo}\left(\eta^{5}-\right.\right.$ $\left.\left.\mathrm{C}_{5} \mathrm{Me}_{5}\right) \mathrm{Cl}_{3}\left\{\eta^{2}-\mathrm{S}_{2} \mathrm{P}(\mathrm{OEt})_{2}\right\}\right]$ (3) with the atomic numbering scheme.

ammonium halide is almost completely insoluble and readily separated by filtration. However the final product was always accompanied by an unidentified residue, which could not be prevented by using two equivalents of the reagent [3b]. Washing the resulting solid with diethylether easily separated this minor component, although the final yield was lowered.

The formulation of these complexes as mononuclear 17-electron compounds is consistent with their spectral properties, mass spectra and magnetic behaviour (see Scheme 3). Thus, all of the complexes 1-4 are paramagnetic with $\mu_{\text {eff }}$ between 1.60 and $1.71 \mathrm{BM}$ at $300 \mathrm{~K}$ as expected for species with one unpaired electron. The IR spectra of both dithiocarbamate complexes $\mathbf{1}$ and $\mathbf{2}$ showed one strong $v(\mathrm{CN})$ absorption at 1516 and 1517 $\mathrm{cm}^{-1}$ and one $v(\mathrm{CS})$ absorption at 1076 and 1074 $\mathrm{cm}^{-1}$, respectively, which can be attributable to a bidentate $\left[\mathrm{S}_{2} \mathrm{CNEt}_{2}\right]$ ligand. Similarly both dithiophosphate complexes 3 and $\mathbf{4}$ showed one $v(\mathrm{PS})$ absorption at 638 and $642 \mathrm{~cm}^{-1}$, consistent with a chelating ligand. The bidentate coordination of the ligand led to a pseudo-octahedral disposition in which the two Sdonor atoms may occupy two equatorial or one equatorial and one axial positions. In order to obtain additional information the molecular structure of complex 3, shown in Fig. 1 with its atomic labelling scheme, was determined by an X-ray diffraction study. Selected bond distances and angles are given in Table 1.

The coordination around the molybdenum atom can be described as octahedral if the centroid of the cyclopentadienyl ring is considered as occupying a single coordination site. One of the ligand sulphur atoms is located trans to the cyclopentadienyl ring whereas the other is in the equatorial plane together with the three chlorine atoms. This equatorial plane is parallel to the cyclopentadienyl plane $\left[0.3(2)^{\circ}\right]$ and the molybdenum atom is located at $0.561 \AA$ above it. The Mo-S bond distance trans to the ring is $0.092 \AA$ longer than that in the equatorial position, this difference is similar to that 
Table 1

Selected bond lengths $(\AA)$ and angles $\left(^{\circ}\right)$ for $\mathbf{3}^{\mathrm{a}}$

\begin{tabular}{|c|c|}
\hline \multicolumn{2}{|l|}{ Bond length } \\
\hline $\operatorname{Mo}(1)-\mathrm{C}(2)$ & $2.370(8)$ \\
\hline $\mathrm{Mo}(1)-\mathrm{C}(1)$ & $2.375(8)$ \\
\hline $\mathrm{Mo}(1)-\mathrm{Cl}(1)$ & $2.411(2)$ \\
\hline $\operatorname{Mo}(1)-\mathrm{Cl}(2)$ & $2.417(2)$ \\
\hline $\mathrm{Mo}(1)-\mathrm{Cl}(3)$ & $2.432(2)$ \\
\hline $\operatorname{Mo}(1)-C(3)$ & $2.430(7)$ \\
\hline $\mathrm{Mo}(1)-\mathrm{C}(5)$ & $2.436(7)$ \\
\hline $\mathrm{Mo}(1)-\mathrm{C}(4)$ & $2.462(7)$ \\
\hline $\operatorname{Mo}(1)-S(1)$ & $2.508(2)$ \\
\hline $\mathrm{Mo}(1)-\mathrm{S}(2)$ & $2.600(2)$ \\
\hline $\mathrm{S}(1)-\mathrm{P}(1)$ & $1.998(3)$ \\
\hline $\mathrm{S}(2)-\mathrm{P}(1)$ & $1.978(3)$ \\
\hline $\mathrm{P}(1)-\mathrm{O}(1)$ & $1.551(6)$ \\
\hline $\mathrm{P}(1)-\mathrm{O}(2)$ & $1.552(6)$ \\
\hline $\mathrm{O}(2)-\mathrm{C}(8)$ & $1.445(13)$ \\
\hline $\mathrm{O}(1)-\mathrm{C}(6)$ & $1.425(12)$ \\
\hline$C(1)-C(5)$ & $1.419(11)$ \\
\hline $\mathrm{C}(1)-\mathrm{C}(2)$ & $1.417(12)$ \\
\hline $\mathrm{C}(1)-\mathrm{C}(11)$ & $1.471(12)$ \\
\hline $\mathrm{C}(2)-\mathrm{C}(3)$ & $1.402(11)$ \\
\hline$C(2)-C(12)$ & $1.476(11)$ \\
\hline $\mathrm{C}(3)-\mathrm{C}(4)$ & $1.391(11)$ \\
\hline$C(3)-C(13)$ & $1.494(11)$ \\
\hline$C(4)-C(5)$ & $1.389(11)$ \\
\hline$C(4)-C(14)$ & $1.520(11)$ \\
\hline$C(5)-C(15)$ & $1.461(11)$ \\
\hline$C(6)-C(7)$ & $1.38(2)$ \\
\hline $\mathrm{C}(8)-\mathrm{C}(9)$ & $1.23(2)$ \\
\hline $\mathrm{Mo}(1)-\mathrm{Cp}(1)$ & 2.099 \\
\hline \multicolumn{2}{|l|}{ Bond angle } \\
\hline $\mathrm{Cl}(1)-\mathrm{Mo}(1)-\mathrm{Cl}(2)$ & $83.74(9)$ \\
\hline $\mathrm{Cl}(1)-\mathrm{Mo}(1)-\mathrm{Cl}(3)$ & $85.38(9)$ \\
\hline $\mathrm{Cl}(2)-\mathrm{Mo}(1)-\mathrm{Cl}(3)$ & $154.38(8)$ \\
\hline $\mathrm{Cl}(1)-\mathrm{Mo}(1)-\mathrm{S}(1)$ & $151.90(8)$ \\
\hline $\mathrm{Cl}(2)-\mathrm{Mo}(1)-\mathrm{S}(1)$ & $88.81(8)$ \\
\hline $\mathrm{Cl}(3)-\mathrm{Mo}(1)-\mathrm{S}(1)$ & $89.98(8)$ \\
\hline $\mathrm{Cl}(1)-\mathrm{Mo}(1)-\mathrm{S}(2)$ & $76.64(8)$ \\
\hline $\mathrm{Cl}(2)-\mathrm{Mo}(1)-\mathrm{S}(2)$ & $77.84(8)$ \\
\hline $\mathrm{Cl}(3)-\mathrm{Mo}(1)-\mathrm{S}(2)$ & $77.11(7)$ \\
\hline $\mathrm{S}(1)-\mathrm{Mo}(1)-\mathrm{S}(2)$ & $75.30(7)$ \\
\hline $\mathrm{P}(1)-\mathrm{S}(1)-\mathrm{Mo}(1)$ & $91.73(10)$ \\
\hline $\mathrm{P}(1)-\mathrm{S}(2)-\mathrm{Mo}(1)$ & $89.54(10)$ \\
\hline $\mathrm{O}(1)-\mathrm{P}(1)-\mathrm{O}(2)$ & $96.2(4)$ \\
\hline $\mathrm{O}(1)-\mathrm{P}(1)-\mathrm{S}(2)$ & $116.0(3)$ \\
\hline $\mathrm{O}(2)-\mathrm{P}(1)-\mathrm{S}(2)$ & $115.1(3)$ \\
\hline $\mathrm{O}(1)-\mathrm{P}(1)-\mathrm{S}(1)$ & $112.8(3)$ \\
\hline $\mathrm{O}(2)-\mathrm{P}(1)-\mathrm{S}(1)$ & $113.8(3)$ \\
\hline$S(2)-P(1)-S(1)$ & $103.42(13)$ \\
\hline $\mathrm{C}(8)-\mathrm{O}(2)-\mathrm{P}(1)$ & $124.4(6)$ \\
\hline $\mathrm{C}(6)-\mathrm{O}(1)-\mathrm{P}(1)$ & $122.3(6)$ \\
\hline $\mathrm{C}(7)-\mathrm{C}(6)-\mathrm{O}(1)$ & $114.6(11)$ \\
\hline $\mathrm{C}(9)-\mathrm{C}(8)-\mathrm{O}(2)$ & $118.3(12)$ \\
\hline $\mathrm{Cl}(1)-\mathrm{Mo}(1)-\mathrm{Cp}(1)$ & 107.1 \\
\hline $\mathrm{Cl}(2)-\mathrm{Mo}(1)-\mathrm{Cp}(1)$ & 102.7 \\
\hline $\mathrm{Cl}(3)-\mathrm{Mo}(1)-\mathrm{Cp}(1)$ & 102.6 \\
\hline $\mathrm{S}(1)-\mathrm{Mo}(1)-\mathrm{Cp}(1)$ & 100.9 \\
\hline $\mathrm{S}(2)-\mathrm{Mo}(1)-\mathrm{Cp}(1)$ & 176.2 \\
\hline
\end{tabular}

${ }^{\text {a }} \mathrm{Cp}(1)$ is the centroid of $\mathrm{C}(1)-\mathrm{C}(5)$.

found for the related niobium complex $\left[\mathrm{NbCpCl}_{3}\left({ }^{\mathrm{i}} \mathrm{Pr}_{2} \mathrm{dtp}\right)\right][3 \mathrm{~b}]$.

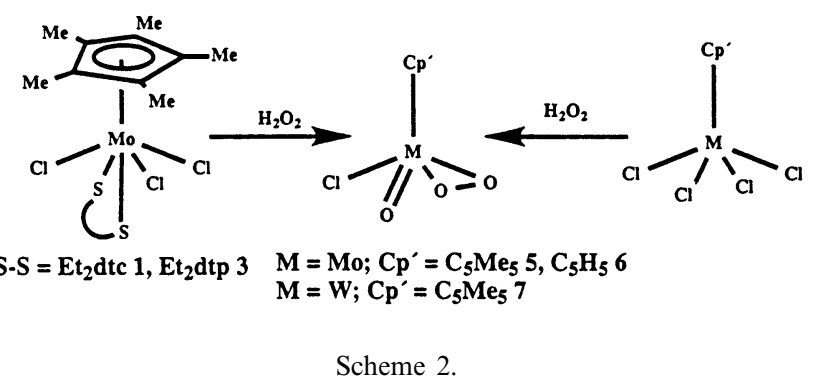

All the complexes 1-4 were reasonably air stable both in solution and in the solid state although stirring their solutions in the presence of air resulted in partial oxidation and hydrolysis with elimination of free dithioacid, whereas oxidation did not take place when dry oxygen was used.

\subsection{Reactions with $\mathrm{H}_{2} \mathrm{O}_{2}$}

Reaction of complexes $\mathbf{1}$ and $\mathbf{3}$ with aqueous hydrogen peroxide (Scheme 2) led to the formation of the reported [5] peroxo complex $[\mathrm{MoCp} * \mathrm{Cl}(\mathrm{O}-\mathrm{O}) \mathrm{O}] \mathbf{5}$, which could also be obtained by reacting the starting tetrachloro-molybdenum(V) compound under the same conditions. The same reaction was used to prepare the related halo complexes $\left[\mathrm{MCp}^{\prime} \mathrm{Cl}(\mathrm{O}-\mathrm{O}) \mathrm{O}\right]$ $\left(\mathrm{M}=\mathrm{Mo}, \mathrm{Cp}^{\prime}=\eta^{5}-\mathrm{C}_{5} \mathrm{H}_{5} 6 ; \mathrm{M}=\mathrm{W}, \mathrm{Cp}^{\prime}=\eta^{5}-\mathrm{C}_{5} \mathrm{Me}_{5} 7\right)$ similar to those previously reported $[5,6]$ alkyl peroxo derivatives. Complexes 5-7 were soluble in chlorinated solvents, partially soluble in toluene and insoluble in alkanes being air stable but thermally unstable substances which slowly decompose at room temperature to give blue $(\mathrm{Mo})$ and grey $(\mathrm{W})$ unidentified residues after 3 days. Their IR spectra showed $v(\mathrm{O}-\mathrm{O})$ and $v(\mathrm{M}=\mathrm{O})$ absorptions between $842-883$ and 934-961 $\mathrm{cm}^{-1}$, respectively consistent with their formulation as mononuclear compounds with terminal $\mathrm{M}=\mathrm{O}$ bonds and $\eta^{2}$-coordinated peroxo ligands.

The molecular structure of complex 6 was determined by X-ray diffraction methods. The oxo $\mathrm{O}(1)$ atom and the peroxo $\mathrm{O}(2)-\mathrm{O}(3)$ group are disorderedly distributed in two positions of equivalent occupancy factors, so that the complex has an imposed crystallographic $C_{s}$ symmetry with the mirror plane passing through the $\mathrm{Mo}, \mathrm{Cl}$ and $\mathrm{C}(1)$ atoms. Views of the two images together with the atomic numbering scheme are depicted in Fig. 2. The bond distances and angles are given in Table 2 .

If the $\mathrm{Cp}$ centroid and the midpoint of the peroxo group, $\mathrm{M}(1)$, are considered as coordination sites, the coordination geometry around molybdenum can be envisaged as a three-legged piano stool. The dihedral angle between the $\mathrm{Cp}$ ring and the $\mathrm{ClO}(1) \mathrm{M}(1)$ plane is $175.2(6)^{\circ}$. If the structure of the complex is considered as pseudo-square pyramidal, the Mo atom is out of 

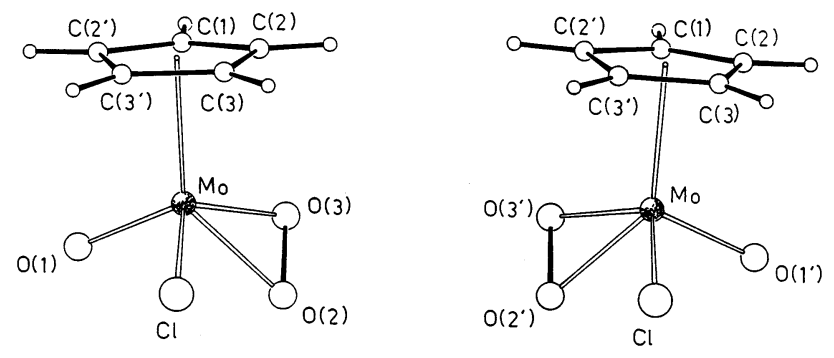

Fig. 2. View of the two images of the disordered compound $\left[\mathrm{Mo}\left(\eta^{5}\right.\right.$ $\left.\left.\mathrm{C}_{5} \mathrm{H}_{5}\right) \mathrm{Cl}(\mathrm{O})\left(\eta^{2}-\mathrm{O}-\mathrm{O}\right)\right](6)$ with the atomic numbering scheme.

0.790(1) $\AA$ from the basal $\mathrm{ClO}(1) \mathrm{O}(2) \mathrm{O}(3)$ mean plane. The structure of 6 is similar to those found for [W( $\eta^{5}-$ $\left.\mathrm{C}_{5} \mathrm{H}_{5}\right)(\mathrm{O})\left(\eta^{2}-\mathrm{O}_{2}\right)\left(\mathrm{CH}_{2} \mathrm{SiMe}_{3}\right)$ ] [6] and [W( $\left.\eta^{5}-\mathrm{C}_{5} \mathrm{Me}_{5}\right)-$ $(\mathrm{O})\left(\eta^{2}-\mathrm{O}_{2}\right)\left(\mathrm{CH}_{2} \mathrm{SiMe}_{3}\right)$ ] [5a]. The $\mathrm{Cp}$ ring interacts with the $\mathrm{Mo}$ atom in a slightly asymmetrical fashion (the Mo-C distances are in the range 2.289(9)-2.402(8) $\AA$ ). The $\mathrm{Mo}(\mathrm{VI})-\mathrm{Cl}$ bond length, 2.310(3) $\AA$, is, as expected, shorter than those found for the $\mathrm{Mo}(\mathrm{V})-\mathrm{Cl}$ bonds in 3 (ranging from 2.411(2) to 2.432(2) $\AA$ and slightly shorter than the mean value $(2.389 \AA)$ reported

Table 2

Selected bond lengths $(\AA)$ and angles $\left(^{\circ}\right)$ for $6^{\text {a }}$

\begin{tabular}{|c|c|}
\hline \multicolumn{2}{|l|}{ Bond length } \\
\hline Mo-CE1 & $2.080(8)$ \\
\hline Mo-M1 & $1.748(18$ \\
\hline $\mathrm{Mo}-\mathrm{Cl}$ & $2.310(3)$ \\
\hline Mo-O1 & $1.771(19$ \\
\hline $\mathrm{Mo}-\mathrm{O} 2$ & $1.887(13$ \\
\hline Mo-O3 & $1.860(22$ \\
\hline $\mathrm{Mo}-\mathrm{Cl}$ & $2.289(9)$ \\
\hline $\mathrm{Mo}-\mathrm{C} 2$ & $2.387(8)$ \\
\hline Mo-C3 & $2.402(8)$ \\
\hline $\mathrm{O} 2-\mathrm{O} 3$ & $1.352(21$ \\
\hline $\mathrm{C} 1-\mathrm{C} 2$ & $1.331(14$ \\
\hline $\mathrm{C} 2-\mathrm{C} 3$ & $1.339(16$ \\
\hline $\mathrm{C} 3-\mathrm{C} 3^{\prime}$ & $1.392(11$ \\
\hline \multicolumn{2}{|l|}{ Bond angle } \\
\hline CE1-Mo-O1 & $114.4(7)$ \\
\hline CE1-Mo-Cl & 107.7(3) \\
\hline CE1-Mo-M1 & $123.4(6)$ \\
\hline Cl-Mo-O1 & $100.2(7)$ \\
\hline $\mathrm{Cl}-\mathrm{Mo}-\mathrm{O} 2$ & $82.1(5)$ \\
\hline $\mathrm{Cl}-\mathrm{Mo}-\mathrm{O} 3$ & $122.7(6)$ \\
\hline $\mathrm{O} 1-\mathrm{Mo}-\mathrm{O} 2$ & $104.2(7)$ \\
\hline $\mathrm{O} 1-\mathrm{Mo}-\mathrm{O} 3$ & $105.2(8)$ \\
\hline $\mathrm{O} 2-\mathrm{Mo}-\mathrm{O} 3$ & $42.3(7)$ \\
\hline O1-Mo-M1 & $105.8(8)$ \\
\hline Cl-Mo-M1 & $102.3(6)$ \\
\hline CE1-Mo-O2 & $137.2(4)$ \\
\hline CE1-Mo-O3 & $107.0(6)$ \\
\hline $\mathrm{Mo}-\mathrm{O} 2-\mathrm{O} 3$ & $67.8(10)$ \\
\hline $\mathrm{Mo}-\mathrm{O} 3-\mathrm{O} 2$ & $69.9(10)$ \\
\hline $\mathrm{C} 2-\mathrm{C} 1-\mathrm{C} 2^{\prime}$ & $110.7(6)$ \\
\hline $\mathrm{C} 1-\mathrm{C} 2-\mathrm{C} 3$ & 107.1(9) \\
\hline $\mathrm{C} 2-\mathrm{C} 3-\mathrm{C}^{\prime}$ & $107.4(8)$ \\
\hline
\end{tabular}

${ }^{\text {a }} \mathrm{CE} 1$ is the centroid of the $\mathrm{Cp}$ ring and M1 the midpoint of the $\mathrm{O} 2-\mathrm{O} 3$ bond. Key to symmetry operation: $-x, 1 / 2-y,-z$. for $\mathrm{Mo}(\mathrm{VI})-\mathrm{Cl}$ bonds [7]). The $\mathrm{Mo}-\mathrm{O}(1)$ bond length, 1.771(19) $\AA$, is longer than the average value found for the $\mathrm{Mo}=\mathrm{O}$ bonds $(1.693 \AA)$ [7]. The $\mathrm{Mo}-\mathrm{O}(2)$ and $\mathrm{Mo}-\mathrm{O}(3)$ bond lengths, 1.887(13) and 1.860(22) $\AA$, are comparable to the ones found for $\mathrm{W}-\mathrm{O}$ bonds in tungsten-peroxo complexes [5a,6], whereas the $\mathrm{O}(2)-$ $\mathrm{O}(3)$ bond length, $1.352(21) \AA$, is sligthly shorter than those found in peroxo complexes (in the range 1.4-1.5 A) [7].

\subsection{Reduction reactions}

Reduction of THF solutions of the dithiocarbamate and -phosphate-metal(V) complexes 1-4 with one equivalent of $10 \% \mathrm{Na} / \mathrm{Hg}$ gave mixtures of paramagnetic compounds which could not be resolved. The major component in these mixtures seemed to be the dichloro derivatives $\left[\mathrm{MCp}^{*} \mathrm{Cl}_{2}(\mathrm{~S}-\mathrm{S})\right]$, always accompanied by variable minor amounts of reduced products which did not contain the dithio ligand. However, the 16-electron dithiophosphate-molybdenum complex $\left[\mathrm{MCp}^{*} \mathrm{Cl}_{2}\left(\mathrm{Et}_{2} \mathrm{dtp}\right)\right] \mathbf{8}$ was obtained by reduction of the starting tetrachloro derivative with one equivalent of $10 \% \mathrm{Na} / \mathrm{Hg}$ and a further addition of one equivalent of ammonium dithiophosphate to the resulting filtered solution of $\left[\mathrm{Mo}\left(\eta^{5}-\mathrm{C}_{5} \mathrm{Me}_{5}\right) \mathrm{Cl}_{3}\right]$. The same product was also isolated in $80 \%$ yield when, attempting to obtain the alkylated product, the trichloro complex $\mathbf{3}$ was treated with one equivalent of $\mathrm{MgClMe}$ in a reaction which proceeded with spontaneous reductive elimination. When an analogous reaction was carried out using three equivalents of $\mathrm{Na} / \mathrm{Hg}$ in the presence of $\mathrm{CN}^{t} \mathrm{Bu}$ a further reduction ocurred to give the 18-electron molybdenum(II) complex $\left[\mathrm{MCp}^{*}\left(\mathrm{Et}_{2} \mathrm{dtp}\right)\left(\mathrm{CN}^{t} \mathrm{Bu}\right)_{2}\right] 9$ in high yield.

Formulation of complexes $\mathbf{8}$ and $\mathbf{9}$ as mononuclear species containing the chelating dithiophosphate ligand is consistent with their mass spectra and the $v(\mathrm{PS})$ absorptions observed in their IR spectra at 652 and 677 $\mathrm{cm}^{-1}$, respectively. The paramagnetic behavior observed for complex 8 with $\mu_{\text {eff }}=2.75 \mathrm{BM}$ at $300 \mathrm{~K}$ is consistent with the spin-triplet state expected for a pseudo-square pyramidal compound [8]. The ${ }^{1} \mathrm{H}-\mathrm{NMR}$ spectrum recorded at $-50^{\circ} \mathrm{C}$ in $\mathrm{CDCl}_{3}$ showed one signal for the pentamethylcyclopentadienyl ring protons and two sets of signals for non-equivalent ethoxide groups. The spin-lattice relaxation time values $\left(T_{1}\right)$ for 8 (see Section 3) were consistent with the pseudo-contact shift nature of the NMR parameters [9] indicating the localization of the unpaired spin density into the Cp*-Mo moiety and the different endo and exo orientations of the two ethoxide groups (see Scheme 3).

In contrast, the ${ }^{1} \mathrm{H}-\mathrm{NMR}$ spectrum of the diamagnetic 18-electron complex 9 showed one signal for $t$-butyl groups of two equivalent isocyanide ligands which show a broad $v(\mathrm{CN})$ absorption between 1800 


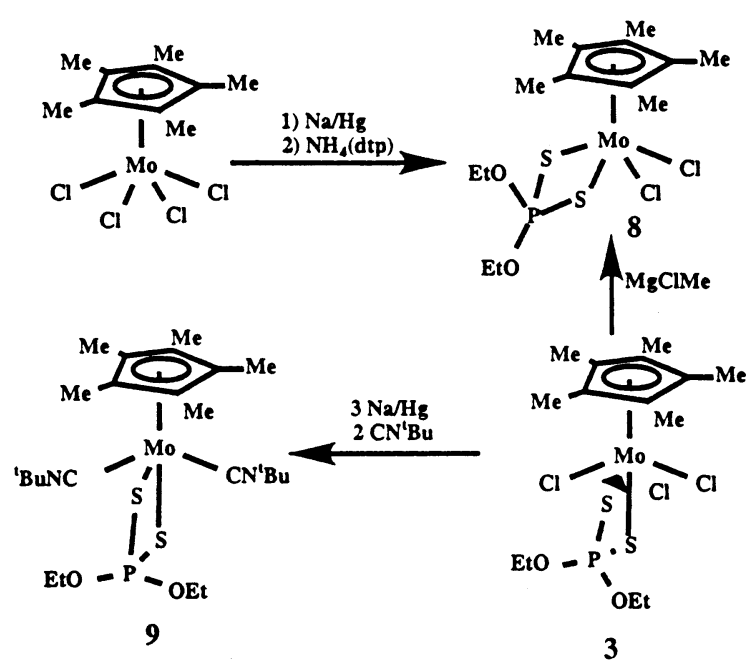

Scheme 3.

\subsection{Preparation of $\left[\mathrm{Mo}\left(\eta^{5}-\mathrm{C}_{5} \mathrm{Me}_{5}\right) \mathrm{Cl}_{3}\left(\mathrm{~S}_{2} \mathrm{CNEt}_{2}\right)\right]$ (1)}

Solid silver diethyldithiocarbamate $(0.69 \mathrm{~g}, 2.70$ $\mathrm{mmol})$ was added to a stirred suspension of $\left[\mathrm{Mo}\left(\eta^{5}\right.\right.$ $\left.\left.\mathrm{C}_{5} \mathrm{Me}_{5}\right) \mathrm{Cl}_{4}\right](1.00 \mathrm{~g}, 2.70 \mathrm{mmol})$ in a $1 / 1$ mixture of $\mathrm{CH}_{2} \mathrm{Cl}_{2} / \mathrm{Et}_{2} \mathrm{O}(70 \mathrm{ml})$ at room temperature. The purple colour of the suspension changed rapidly to give a brown solution and a white precipitate of $\mathrm{AgCl}$, the solution was stirred for an additional $4 \mathrm{~h}$ and then filtered. The solvent was removed under vacuum and the resulting microcrystalline red solid was washed with ethanol to give $\mathbf{1}$ in $80 \%$ yield (1.05 g, $2.16 \mathrm{mmol})$. IR (Nujol) $\mathrm{cm}^{-1}$ : $1516 \mathrm{vs,} 1076 \mathrm{~m}, 386 \mathrm{mw}, 345 \mathrm{~m}, 315$ ms, $296 \mathrm{~ms}$. MS (70 eV, EI), $m / z(\%): 451(7.5)\left[M^{+}-\right.$ $\mathrm{Cl}], 268$ (7.8) $\left.\left[\mathrm{M}^{+}-2 \mathrm{Cl}-\mathrm{Et}_{2} \mathrm{dtc}\right)\right], 119$ (24.6) $\left[\mathrm{Cp}^{*+}-\right.$ $\left.2 \mathrm{CH}_{4}\right], \quad 116$ (100) $\quad\left[\mathrm{Et}_{2} \mathrm{dtc}^{+}-2 \mathrm{CH}_{4}\right], \quad 88 \quad$ (64.5) $\left[\mathrm{Et}_{2} \mathrm{dtc}^{+}-2 \mathrm{C}_{2} \mathrm{H}_{6}\right] . \mathrm{C}_{15} \mathrm{H}_{25} \mathrm{Cl}_{3} \mathrm{MoNS}_{2}$ (485.80): Anal. Calc. C 37.08, H 5.19, N 2.88. Found C 37.00, H 5.46, $\mathrm{N} 2.82 . \mu_{\text {eff }}(300 \mathrm{~K})=1.71 \mathrm{BM}$.

\subsection{Preparation of $\left[\mathrm{W}\left(\eta^{5}-\mathrm{C}_{5} \mathrm{Me}_{5}\right) \mathrm{Cl}_{3}\left(\mathrm{~S}_{2} \mathrm{CNEt}_{2}\right)\right]$}

\section{(2)}

Solid silver diethyldithiocarbamate $(0.51 \mathrm{~g}, 2.00$ $\mathrm{mmol})$ was added to a stirred suspension of $\left[\mathrm{W}\left(\eta^{5}\right.\right.$ $\left.\left.\mathrm{C}_{5} \mathrm{Me}_{5}\right) \mathrm{Cl}_{4}\right](0.92 \mathrm{~g}, 2.00 \mathrm{mmol})$ in a $1 / 1$ mixture of $\mathrm{CH}_{2} \mathrm{Cl}_{2} / \mathrm{Et}_{2} \mathrm{O}(70 \mathrm{ml})$ at room temperature. The reaction mixture was stirred for $10 \mathrm{~h}$ and then the white precipitate of $\mathrm{AgCl}$ was filtered. The solvent was removed under vacuum and the resulting microcrystalline green-brown solid was washed with diethylether $(3 \times$ $15 \mathrm{ml})$ to give 2 in $70 \%$ yield $(0.80 \mathrm{~g}, 1.40 \mathrm{mmol})$. IR (Nujol) $\mathrm{cm}^{-1}$ : $1517 \mathrm{vs}, 1074 \mathrm{~m}, 396 \mathrm{mw}, 334 \mathrm{~m}, 294 \mathrm{~s}$. MS (70 eV, EI), $m / z(\%): 425$ (9.5) $\left[M^{+}-\mathrm{Et}_{2} \mathrm{dtc}\right], 391$ (13.2) $\left[M^{+}-\mathrm{Cl}\right], \quad 135 \quad(26.7) \quad\left[\mathrm{Cp}^{*+}\right], \quad 116 \quad(100)$ $\left[\mathrm{Et}_{2} \mathrm{dtc}^{+}-2 \mathrm{CH}_{4}\right], \quad 105 \quad(47.8) \quad\left[\mathrm{Cp}^{*+}-\mathrm{C}_{2} \mathrm{H}_{6}\right]$. $\mathrm{C}_{15} \mathrm{H}_{25} \mathrm{Cl}_{3} \mathrm{NS}_{2} \mathrm{~W}$ (573.71): Anal. Calc. C 31.40, H 4.39, $\mathrm{N}$ 2.44. Found $\mathrm{C} 31.03, \mathrm{H} 4.02, \mathrm{~N}$ 2.66. $\mu_{\mathrm{eff}}(300$ $\mathrm{K})=1.60 \mathrm{BM}$.

\subsection{Preparation of $\left[\mathrm{Mo}\left(\eta^{5}-\mathrm{C}_{5} \mathrm{Me}_{5}\right) \mathrm{Cl}_{3}\left\{\mathrm{~S}_{2} \mathrm{P}(\mathrm{OEt})_{2}\right\}\right]$ (3)}

Solid ammonium diethyldithiophosphate (1.10 g, $5.36 \mathrm{mmol}$ ) was added to a stirred suspension of $\left[\mathrm{Mo}\left(\eta^{5}-\mathrm{C}_{5} \mathrm{Me}_{5}\right) \mathrm{Cl}_{4}\right](2.20 \mathrm{~g}, 5.36 \mathrm{mmol})$ in a $1 / 4$ mixture of $\mathrm{CH}_{2} \mathrm{Cl}_{2} / \mathrm{Et}_{2} \mathrm{O}(60 \mathrm{ml})$ at room temperature. The reaction was complete after $6 \mathrm{~h}$ stirring leading to a red solution. The $\mathrm{NH}_{4} \mathrm{Cl}$ precipitate was filtered and the solvent was removed under vacuum to give a red residue, which after being washed with diethylether $(2 \times 25 \mathrm{ml})$ provided an insoluble red residue. The solid can be recrystallized from toluene by cooling to $-40^{\circ} \mathrm{C}$ or from $\mathrm{CH}_{2} \mathrm{Cl}_{2}$ by addition of hexane to give brown crystalline needles of 3 in $70 \%$ yield $(1.90 \mathrm{~g}, 3.63 \mathrm{mmol})$ after purification. IR (Nujol) $\mathrm{cm}^{-1}: 1012 \mathrm{vs}, 966 \mathrm{~s}, 819$ s, 798 vs, $638 \mathrm{~ms}, 371 \mathrm{~m}, 312 \mathrm{~m}$. MS (70 eV, EI), m/z (\%): 451 (20.1) $\left[M^{+}-2 \mathrm{Cl}\right], 337$ (27.8) $\left[M^{+}-\mathrm{Et}_{2} \mathrm{dtp}\right]$, 
155 (59.7) $\quad\left[\mathrm{Et}_{2} \mathrm{dtp}^{+}-2 \mathrm{CH}_{4}\right], 135$ (26.7) $\left[\mathrm{Cp}^{*+}\right]$. $\mathrm{C}_{14} \mathrm{H}_{25} \mathrm{Cl}_{3} \mathrm{MoO}_{2} \mathrm{PS}_{2}$ (522.75): Anal. Calc. C 32.17, H 4.82. Found $\mathrm{C} 31.98, \mathrm{H}$ 5.13. $\mu_{\mathrm{eff}}(300 \mathrm{~K})=1.63 \mathrm{BM}$.

\subsection{Preparation of $\left[\mathrm{W}\left(\eta^{5}-\mathrm{C}_{5} \mathrm{Me}_{5}\right) \mathrm{Cl}_{3}\left\{\mathrm{~S}_{2} \mathrm{P}(\mathrm{OEt})_{2}\right\}\right]$ (4)}

Solid ammonium diethyldithiophosphate $(0.90 \mathrm{~g}$, $4.38 \mathrm{mmol})$ was added to a stirred suspension of [W( $\eta^{5}$ $\left.\left.\mathrm{C}_{5} \mathrm{Me}_{5}\right) \mathrm{Cl}_{4}\right](2.02 \mathrm{~g}, 4.38 \mathrm{mmol})$ in a $1 / 4$ mixture of $\mathrm{CH}_{2} \mathrm{Cl}_{2} / \mathrm{Et}_{2} \mathrm{O}(50 \mathrm{ml})$ at room temperature. The reaction was complete after $10 \mathrm{~h}$ stirring leading to a solution from which the $\mathrm{NH}_{4} \mathrm{Cl}$ precipitate was filtered off and the solvent was removed under vacuum to give a yellow-gold residue which was washed with diethylether $(2 \times 25 \mathrm{ml})$. The solid was extracted with warm toluene and crystallized by cooling to room temperature to give $\mathbf{4}$ as a crystalline solid in 55\% (1.47 $\mathrm{g}, 2.41 \mathrm{mmol}$ ) yield after purification. IR (Nujol) $\mathrm{cm}^{-1}$ : 1013 vs, 967 s, 821 s, 799 vs, 642 ms, 364 m, 290 m. MS (70 eV, EI), $m / z$ (\%): 423 (10.2) $\left[M^{+}-\mathrm{Et}_{2} \mathrm{dtp}\right], 391$ (13.2) $\left[M^{+}-\mathrm{Et}_{2} \mathrm{dtp}-\mathrm{Cl}\right], 354$ (16.3) $\left[\mathrm{M}^{+}-\mathrm{Et}_{2} \mathrm{dtp}-\right.$ 2Cl],188 (44.8) [ $\mathrm{Et}_{2} \mathrm{dttp}^{+}$], 97 (100) $\left[\mathrm{Et}_{2} \mathrm{dtp}^{+}-2(\mathrm{OEt})\right]$. $\mathrm{C}_{14} \mathrm{H}_{25} \mathrm{Cl}_{3} \mathrm{O}_{2} \mathrm{PS}_{2} \mathrm{~W}$ (610.66): Anal. Calc. C 27.54, H 3.09. Found $\mathrm{C} 27.13, \mathrm{H}$ 3.97. $\mu_{\mathrm{eff}}(300 \mathrm{~K})=1.69 \mathrm{BM}$.

\subsection{Preparation of $\left[\mathrm{Mo}\left(\eta^{5}-\mathrm{C}_{5} \mathrm{Me}_{5}\right) \mathrm{Cl}(\mathrm{O}-\mathrm{O})(\mathrm{O})\right]$ (5)}

Procedure 1: An aqueous solution of hydrogen peroxide $(1.00 \mathrm{ml}, 10 \mathrm{mmol})$ was added to a solution of $\left.\left[\mathrm{Mo}\left(\eta^{5}-\mathrm{C}_{5} \mathrm{Me}_{5}\right) \mathrm{Cl}_{3}\left\{\mathrm{~S}_{2} \mathrm{P}(\mathrm{OEt})_{2}\right)\right\}\right](1.10 \mathrm{~g}, 2.10 \mathrm{mmol})$ in dichloromethane $(70 \mathrm{ml})$. The mixture was stirred for 2 $\mathrm{h}$ at room temperature to give a yellow-orange solution which was filtered. Evaporation of the solvent under vacuum provided $\mathbf{5}$ as a yellow crystalline solid in $50 \%$ yield $(0.33 \mathrm{~g}, 1.05 \mathrm{mmol})$.

Procedure 2: An aqueous solution (110 vol) of hydrogen peroxide $(0.42 \mathrm{ml}, 4.23 \mathrm{mmol})$ was added to a suspension of $\left[\mathrm{Mo}\left(\eta^{5}-\mathrm{C}_{5} \mathrm{Me}_{5}\right) \mathrm{Cl}_{4}\right](1.05 \mathrm{~g}, 1.41 \mathrm{mmol})$ in dichloromethane $(50 \mathrm{ml})$. The mixture was stirred for $1 \mathrm{~h}$ at room temperature to give a yellow-orange solution which was filtered. Evaporation of the solvent under vacuum provided $\mathbf{5}$ as a yellow crystalline solid in $60 \%$ yield $(0.26 \mathrm{~g}, 0.84 \mathrm{mmol}) .{ }^{1} \mathrm{H}-\mathrm{NMR}(300 \mathrm{MHz}$, $\mathrm{CDCl}_{3}, 25^{\circ} \mathrm{C}$ ): $\delta=2.11$ (s, $\mathrm{C}_{5} M e_{5}$ ). IR (Nujol) $\mathrm{cm}^{-1}$ : 938 s, 881 s, 842 s. $\mathrm{C}_{10} \mathrm{H}_{15} \mathrm{ClMoO}_{3}$ (314.62): Anal. Calc. C 38.18, H 4.77. Found C 38.22, H 4.67.

\subsection{Preparation of $\left[\mathrm{Mo}\left(\eta^{5}-\mathrm{C}_{5} \mathrm{H}_{5}\right) \mathrm{Cl}(\mathrm{O}-\mathrm{O})(\mathrm{O})\right](\mathbf{6})$}

An aqueous solution of hydrogen peroxide $(0.30 \mathrm{ml}$, $3.00 \mathrm{mmol}$ ) was added dropwise to a suspension of $\left[\mathrm{Mo}\left(\eta^{5}-\mathrm{C}_{5} \mathrm{H}_{5}\right) \mathrm{Cl}_{4}\right](0.60 \mathrm{~g}, 1.00 \mathrm{mmol})$ in dichloromethane $(50 \mathrm{ml})$ at room temperature. The initially red mixture changed immediately to green and finally gave a yellow solution after $15 \mathrm{~min}$. After separation, the organic layer was filtered and the solvent evaporated under vacuum to give $\mathbf{6}$ as a yellow crystalline solid. Yield $72 \%$ (0.35 g, $1.43 \mathrm{mmol}) .{ }^{1} \mathrm{H}-\mathrm{NMR}(300 \mathrm{MHz}$, $\left.\mathrm{CDCl}_{3}, 25^{\circ} \mathrm{C}\right): \delta=6.69\left(\mathrm{~s}, \mathrm{C}_{5} H_{5}\right)$. IR (Nujol) $\mathrm{cm}^{-1}: 938$ s, 881 s, 842 s. $\mathrm{C}_{5} \mathrm{H}_{5} \mathrm{ClMoO}_{3}(244.48)$ : Anal. Calc. C 24.54, H 2.04. Found C 24.55, H 1.80.

\subsection{Preparation of $\left[\mathrm{W}\left(\eta^{5}-\mathrm{C}_{5} \mathrm{Me}{ }_{5}\right) \mathrm{Cl}(\mathrm{O}-\mathrm{O})(\mathrm{O})\right](7)$}

An aqueous solution of hydrogen peroxide $(0.16 \mathrm{ml}$, $1.60 \mathrm{mmol})$ was added dropwise to a suspension of $\left[\mathrm{W}\left(\eta^{5}-\mathrm{C}_{5} \mathrm{Me}_{5}\right) \mathrm{Cl}_{4} \quad(0.45 \quad \mathrm{~g}, \quad 0.50 \quad \mathrm{mmol})\right.$ in dichloromethane $(50 \mathrm{ml})$ at room temperature. The colour of the mixture changed immediately to green and finally gave a pale yellow solution after $30 \mathrm{~m}$. After separation, the organic layer was filtered and the solvent evaporated under vacuum to give 7 as a colorless crystalline solid. Yield $45 \%(0.36 \mathrm{~g}, 0.89 \mathrm{mmol}) .{ }^{1} \mathrm{H}$ NMR $\left(300 \mathrm{MHz}, \mathrm{CDCl}_{3}, 25^{\circ} \mathrm{C}\right): \delta=1.72\left(\mathrm{~s}, \mathrm{C}_{5} \mathrm{Me}_{5}\right)$. IR (Nujol) $\mathrm{cm}^{-1}$ : $961 \mathrm{~s}, 943 \mathrm{~s}, 859 \mathrm{~s}, 342 \mathrm{~m}$. $\mathrm{C}_{10} \mathrm{H}_{15} \mathrm{ClO}_{3} \mathrm{~W}$ (2332.39): Anal. Calc. C 29.82, H 3.72. Found C 29.87, H 3.65.

\subsection{Preparation of $\left[\mathrm{Mo}\left(\eta^{5}-\mathrm{C}_{5} \mathrm{Me}_{5}\right) \mathrm{Cl}_{2}\left\{\mathrm{~S}_{2} \mathrm{P}(\mathrm{OEt})_{2}\right\}\right]$}

Procedure 1: THF $(50 \mathrm{ml})$ was added to a mixture of $\left[\mathrm{Mo}\left(\eta^{5}-\mathrm{C}_{5} \mathrm{Me}_{5}\right) \mathrm{Cl}_{4}\right](0.70 \mathrm{~g}, 1.88 \mathrm{mmol})$ and $10 \%$ sodium amalgam $(0.045 \mathrm{~g}, 1.97 \mathrm{mmol})$ and the mixture was stirred for $8 \mathrm{~h}$. After filtration, ammonium diethyldithiophosphate $(0.27 \mathrm{~g}, 1.31 \mathrm{mmol})$ was added to the yellow-green solution containing $\left[\mathrm{Mo}\left(\eta^{5}-\right.\right.$ $\left.\mathrm{C}_{5} \mathrm{Me}_{5}\right) \mathrm{Cl}_{3}$ ] to give an orange solution which was stirred for $1 \mathrm{~h}$. The solvent was removed under vacuum and the solid residue was extracted into toluene $(50 \mathrm{ml})$. Compound $\mathbf{8}$ was isolated as an orange solid by removal of the solvent under vacuum and finally washed with diethylether $(2 \times 15 \mathrm{ml})$. Yield $60 \%(0.52 \mathrm{~g}, 1.10$ mmol).

Procedure 2: A $3 \mathrm{M}$ solution of $\mathrm{MgClMe}$ in THF $(0.60 \mathrm{ml}, 1.80 \mathrm{mmol})$ was added to a solution of $\left[\mathrm{Mo}\left(\eta^{5}-\mathrm{C}_{5} \mathrm{Me}_{5}\right) \mathrm{Cl}_{3}\left\{\mathrm{~S}_{2} \mathrm{P}(\mathrm{OEt})_{2}\right\}\right](0.94 \mathrm{~g}, 1.80 \mathrm{mmol})$ in THF $(50 \mathrm{ml})$ at $-60^{\circ} \mathrm{C}$ and the mixture was warmed to room temperature and stirred for $3 \mathrm{~h}$. The resulting solution was filtered and the solvent was removed under vacuum. The solid residue was extracted into toluene and after removal of the solvent under vacuum, compound $\mathbf{8}$ was obtained as an orange microcrystalline solid which was washed with diethylether $(2 \times 15$ $\mathrm{ml})$. Yield $80 \%(0.69 \mathrm{~g}, 1.47 \mathrm{mmol}) .{ }^{1} \mathrm{H}-\mathrm{NMR}$ (500 $\left.\mathrm{MHz}, \mathrm{CDCl}_{3},-50^{\circ} \mathrm{C}\right): \delta=-1.00\left(15 \mathrm{H}, T_{1}=8.87 \mathrm{~ms}\right.$, $\left.\mathrm{C}_{5} \mathrm{Me}_{5}\right), 2.58\left(3 \mathrm{H}, T_{1}=138.8 \mathrm{~ms}, \mathrm{POCH}_{2} \mathrm{CH}_{3}\right.$ exo $)$, $2.82\left(3 \mathrm{H}, T_{1}=138.8 \mathrm{~ms}, \mathrm{POCH}_{2} \mathrm{CH}_{3}\right.$ endo $), 5.03(2 \mathrm{H}$, $T_{1}=44.5 \mathrm{~ms}, \mathrm{POCH}_{2} \mathrm{CH}_{3}$ exo $), 7.80\left(2 \mathrm{H}, T_{1}=5.9 \mathrm{~ms}\right.$, $\mathrm{POCH}_{2} \mathrm{CH}_{3}$ endo). IR (Nujol) cm ${ }^{-1}: 1006 \mathrm{~s}, 969 \mathrm{~s}, 774$ $\mathrm{ms}, 652 \mathrm{~ms}, 387 \mathrm{~m}, 326 \mathrm{~ms}$. MS (70 eV, EI), $m / z(\%)$ : 488 (3.2) $\left[M^{+}\right], 302$ (32.2) $\left[M^{+}-\mathrm{Et}_{2} \mathrm{dtp}\right], 298$ (23.5) $\left[\begin{array}{llllll}\left.M^{+}-2 \mathrm{Cl}\right], & 188 & (100) & {\left[\mathrm{H}_{2}\right.} & \mathrm{Et}_{2} \mathrm{dtp}^{+}\end{array}\right], \quad 97 \quad(41.1)$ 
[Et $\left.\mathrm{dtp}^{+}-2(\mathrm{OEt})\right] . \mathrm{C}_{14} \mathrm{H}_{25} \mathrm{Cl}_{2} \mathrm{MoO}_{2} \mathrm{PS}_{2}$ (487.30): Anal. Calc. C 34.51, H 5.17. Found C 34.81, H 5.00. $\mu_{\text {eff }}$ (300 $\mathrm{K})=2.75 \mathrm{BM}$.

\subsection{Preparation of $\left[\mathrm{Mo}\left(\eta^{5}-\mathrm{C}_{5} \mathrm{Me}_{5}\right)\left\{\mathrm{S}_{2} \mathrm{P}(\mathrm{OEt})_{2}\right\}-\right.$ $\left.\left(\mathrm{CN}^{t} \mathrm{Bu}\right)_{2}\right](\mathbf{9})$}

THF (10 ml), $t$-butylisocyanide $(0.225 \mathrm{~g}, 2.00 \mathrm{mmol})$ and a solution of $\left.\left[\mathrm{Mo}\left(\eta^{5}-\mathrm{C}_{5} \mathrm{Me}_{5}\right) \mathrm{Cl}_{3} \quad\left\{\mathrm{~S} 2 \mathrm{P}(\mathrm{OEt})_{2}\right)\right\}\right]$ $(0.52 \mathrm{~g}, 1.00 \mathrm{mmol})$ in THF $(40 \mathrm{ml})$ were added to $10 \%$ sodium amalgam $(0.073 \mathrm{~g}, 3.18 \mathrm{mmol})$ and the mixture was stirred at room temperature for $1 \mathrm{~h}$. The resulting red solution was filtered and the solvent removed under vacuum. The solid residue was extracted into pentane from which 9 was isolated by evaporation of the solvent under vacuum as a red solid, which was filtered and dried under vacuum. Yield 50\% $(0.27 \mathrm{~g}, 0.47 \mathrm{mmol})$. ${ }^{1} \mathrm{H}-\mathrm{NMR}\left(500 \mathrm{MHz}, \mathrm{C}_{6} \mathrm{D}_{6}, 25^{\circ} \mathrm{C}\right): \delta=1.25(\mathrm{~m}, 6 \mathrm{H}$, $\left.\mathrm{POCH}_{2} \mathrm{CH}_{3}\right), 1.32\left(\mathrm{~s}, 18 \mathrm{H}, \mathrm{CNCMe}_{3}\right), 1.97(\mathrm{~s}, 15 \mathrm{H}$, $\left.\mathrm{C}_{5} \mathrm{Me}_{5}\right), 4,28\left(\mathrm{~m}, 2 \mathrm{H}, J_{\mathrm{H}-\mathrm{H}}=10.2 \mathrm{~Hz} ; J_{\mathrm{P}-\mathrm{H}}=5.4 \mathrm{~Hz}\right.$, $\left.\mathrm{POCH}_{2} \mathrm{CH}_{3}\right), 4.32\left(\mathrm{~m}, 2 \mathrm{H}, J_{\mathrm{H}-\mathrm{H}}=10.2 \mathrm{~Hz} ; J_{\mathrm{P}-\mathrm{H}}=5.4\right.$ $\mathrm{Hz} \mathrm{POCH}_{2} \mathrm{CH}_{3}$ ). IR (Nujol) cm ${ }^{-1}: 2010 \mathrm{sbr}, 1935 \mathrm{sh}$, 1837 sh, 1006 s, 677 ms. $\mathrm{C}_{24} \mathrm{H}_{43} \mathrm{MoN}_{2} \mathrm{O}_{2} \mathrm{PS}_{2}$ (487.30): Anal. Calc. C 49.47, H 7.44 N 4.81. Found C 49.22, H $7.55, \mathrm{~N} 4.60$.

\subsection{Crystal structure determinations}

Crystals of compound $\mathbf{3}$ were obtained by crystallization from toluene/hexane and a suitably sized crystal in a Lindemann tube was mounted on an Enraf-Nonius CAD 4 diffractometer with graphite monochromated Mo $-\mathrm{K}_{\alpha}$ radiation $(\lambda=0.71073 \AA$ ) $)$. Crystals of 6 were obtained by crystallization from dichloromethane/hexane and a suitably sized crystal in a Lindemann tube was mounted on a Philips PW 1100 diffractometer with graphite monochromated $\mathrm{Mo}-\mathrm{K}_{\alpha}$ radiation $(\lambda=$ $0.71073 \AA$ ). Crystallographic and experimental details for both structures are summarized in Table 3 .

The data were corrected for Lorentz and polarization effects in the usual manner. No correction for absorption was made to $\mathbf{3}$, whereas a correction was applied to 6 [maximum and minimum value for the transmission coefficient was 1.000 and 0.5867] [13]. The structure of 3 was solved by direct methods (SHELXL 90) [14] and refined by least squares against $F_{\mathrm{o}}^{2}$ (SHELXL 93) [15]. The structure of $\mathbf{6}$ was solved by Patterson methods [16] and was refined by least-squares (based on $F_{\mathrm{o}}$ ) (SHELX76) [17]. All non hydrogen atoms of 3 were refined anisotropically and the hydrogen atoms were introduced from geometrical calculations and refined using a riding model with fixed thermal parameters. The hydrogen atoms of $\mathbf{6}$ were found in the final DF map and refined isotropically. The final cycles of refinement were carried out on the basis of 208 variables for 3 and 75 for $\mathbf{6}$. The biggest remaining peak in the final difference
Table 3

Summary of crystallographic data for compounds $\mathbf{3}$ and $\mathbf{6}$

\begin{tabular}{|c|c|c|}
\hline & 3 & 6 \\
\hline Formula & $\mathrm{C}_{14} \mathrm{H}_{25} \mathrm{Cl}_{3} \mathrm{O}_{2} \mathrm{~S}_{2} \mathrm{PMo}$ & $\mathrm{C}_{5} \mathrm{H}_{5} \mathrm{ClO}_{3} \mathrm{Mo}$ \\
\hline Molecular weight & 522.72 & 244.49 \\
\hline Crystal system & Monoclinic & Monoclinic \\
\hline Space group & $P 2_{1} / n$ & $P 2_{1} / m$ \\
\hline Radiation $(\lambda, \AA)$ & $\mathrm{Mo}-\mathrm{K}_{\alpha}(0.71073 \AA)$ & $\mathrm{Mo}-\mathrm{K}_{\alpha}(0.71073 \AA)$ \\
\hline$a(\AA)$ & $9.013(2)$ & $6.611(2)$ \\
\hline$b(\AA)$ & $12.457(3)$ & $9.472(3)$ \\
\hline$c(\AA)$ & $19.111(6)$ & $6.579(3)$ \\
\hline$\beta\left({ }^{\circ}\right)$ & $94.51(1)$ & $118.96(2)$ \\
\hline$V\left(\AA^{3}\right)$ & $2139(1)$ & $360.5(2)$ \\
\hline$Z$ & 4 & 2 \\
\hline$D_{\text {calc. }}\left(\mathrm{g} \mathrm{cm}^{-3}\right)$ & 1.623 & 2.252 \\
\hline$F(000)$ & 1060 & 236 \\
\hline Crystal size (mm) & $0.20 \times 0.25 \times 0.30$ & $0.21 \times 0.18 \times 0.26$ \\
\hline$\mu, \mathrm{Mo}-\mathrm{K}_{\alpha}\left(\mathrm{cm}^{-1}\right)$ & 12.62 & 21.28 \\
\hline Diffractometer & Enraf-Nonius CAD-4 & Philips PW 1100 \\
\hline Scan type & $\mathrm{w} / 2 \theta$ & $\theta / 2 \theta$ \\
\hline$\theta$ Range $\left(^{\circ}\right)$ & $2-27$ & $3-27$ \\
\hline Standard reflection & Three every 200 & One every 50 \\
\hline Reflections measured & $4787( \pm h, \pm k, l)$ & $1583( \pm h, \pm k, l)$ \\
\hline Unique total data & 4653 & 844 \\
\hline Unique observed data & $2664[I>2 \sigma(I)]$ & $738[I>3 \sigma(I)]$ \\
\hline$R, R_{1}^{\mathrm{a}}$ & $R_{1}=0.0566$ & $R=0.0460$ \\
\hline$R_{w}, w R_{2}^{\mathrm{a}}$ & $w R_{2}=0.1358$ & $R_{w}=0.0569$ \\
\hline
\end{tabular}

${ }^{\mathrm{a}} R=R_{1}=\Sigma|| F_{\mathrm{o}}|-| F_{\mathrm{c}}|| \Sigma\left|F_{\mathrm{o}}\right|, \quad R_{w}=\left[\Sigma w\left(\left|F_{\mathrm{o}}\right|-\left|F_{\mathrm{c}}\right|\right)^{2} / \Sigma w\left(F_{\mathrm{o}}\right)^{2}\right]^{1 / 2}$, $w R_{2}=\left[\Sigma\left[w\left(F_{\mathrm{o}}^{2}-F_{\mathrm{c}}^{2}\right)^{2}\right] / \Sigma\left[w\left(F_{\mathrm{o}}^{2}\right)^{2}\right]\right]^{1 / 2}$.

map was equivalent to about $1.36,1.51 \mathrm{e} \AA^{-3}$ for $\mathbf{3}$ and 6, respectively. In the case of 3 a weighting scheme $w=1=\left[\sigma^{2} F_{\mathrm{o}}^{2}=(0.0870 P)^{2}=2.1975 P\right]$ where $P=$ $\left(F_{\mathrm{o}}^{2}+2 F_{\mathrm{c}}^{2}\right) / 3$ was used in the last cycles of refinement. In the case of 6 a weighting scheme $w=K\left[\sigma^{2}\left(F_{\mathrm{o}}\right)=\right.$ $\left.g F_{\mathrm{o}}^{2}\right]^{-1}$ was used with $K=0.6181$ and $g=0.0016$. Calculations for 3 were carried out on an ALPHA AXP (Digital) workstation. All calculations for $\mathbf{6}$ were carried out on the Gould Powernode 6040 and Encore 91 computers of the 'Centro di Studio per la Strutturistica Diffrattometrica' del C.N.R., in Parma, Italy.

The final coordinates for the non-hydrogen atoms with the equivalent isotropic thermal parameters, $U_{\text {eq }}$, the coordinates for the hydrogen atoms with the isotropic thermal parameters, anisotropic thermal parameters for the non hydrogen atoms, and a complete list of bond distances, angles and observed and calculated structure factors have been deposited (for both structures).

\section{Supplementary material}

Crystallographic data for the structural analysis has been deposited with the Cambridge Crystallographic Data Centre, CCDC No. 114670 (3), and 114780 (6). 
Copies of the information can be obtained free of charge from The Director, CCDC, 12 Union Road, Cambridge, CB2 1EZ, UK (Fax: + 44-1223-336-033; e-mail: deposit@ccdc.cam.ac.uk or www: http:// www.ccdc.cam.ac.uk.

\section{Acknowledgements}

We acknowledge DGICYT (Project PB97-0776), CAM (I + D 0034/94) and Consiglio Nazionale delle Ricerche (Rome) for their financial support of this research.

\section{References}

[1] (a) J.A. Cras, J. Willemse, in: G. Wilkinson, R.D. Gillard, G.A. McCleverty (Eds.), Comprehensive Coordination Chemistry, vol. 2, Pergamon, Oxford, 1987, pp. 585-587. (b) S.E. Livingstone, in: G. Wilkinson, R.D. Gillard, G.A. McCleverty (Eds.), Comprehensive Coordination Chemistry, vol. 2, Pergamon, Oxford, 1987, pp. 643-644. (c) R.P. Burns, F.P. McCollough, C.A. McAuliffe, Adv. Inorg. Chem. Radiochem. 23 (1979) 211.

[2] (a) R.S.P. Coutts, P.C. Wailes, J. Organomet. Chem. 84 (1975) 47. (b) M.E. Silver, R.C. Fay, Organometallics 2 (1983) 44. (c) A.T. Casey, R.J. Thackeray, Aust. J. Chem. 27 (1974) 757. (d) J.A. McCleverty, A.J. Murray, J. Chem. Soc. Dalton Trans. 1424 (1979).

[3] (a) W. de Oliveira, J.L. Migot, M.B. Gomes de Lima, J. SalaPala, J.E. Guerchais, J.Y. Le Gall, J. Organomet. Chem. 248 (1985) 313. (b) S. Woodward, U. Riaz, M.D. Curtis, B.S. Hagerty, A.L. Rheingold, Organometallics 9 (1990) 2703.
[4] T. Pedraz, M.A. Pellinghelli, P. Royo, A. Tiripicchio, A. Vázquez de Miguel, J. Organomet. Chem. 534 (1997) 27.

[5] (a) J.W. Faller, Y. Ma, Organometallics 7 (1988) 559. (b) J.W. Faller, Y. Ma, J. Organomet. Chem. 368 (1989) 45.

[6] P. Legzdins, E.C. Phillips, S.J. Rettig, L. Sánchez, J. Trotter, V.C. Yee, Organometallics 7 (1988) 1877.

[7] A.G. Orpen, L. Brammer, F.H. Allen, O. Kennard, D.G. Watson, R. Taylor, J. Chem. Soc. Dalton Trans. (1989) S1.

[8] (a) R. Poli, Chem. Rev. 96 (1996) 2135. (b) R. Poli, B.E. Owens, S.T. Krueger, A.L. Rheingold, Polyhedron 1 (1992) 2301. (c) F. Abugideiri, J.C. Gordon, R. Poli, B.E. Owens-Waltermire, A.L. Rheingold, Organometallics 12 (1993) 1575. (d) F. Abugideiri, G.A. Brewer, J.U. Desai, J.C. Gordon, R. Poli, Inorg. Chem. 33 (1994) 3745.

[9] I. Bertini, C. Luchinat, Coord. Chem. Rev. 150 (1996)77.

[10] P. Kubácek, R. Hoffmann, Z. Havlas, Organometallics, 1 (1982) 180.

[11] D.P. Perrin, W.L.F. Armarego, Purification of Laboratory Chemicals, 3, Pergamon, Oxford, 1988.

[12] (a) P. Gómez-Sal, I. Jiménez, A. Martín, T. Pedraz, P. Royo, A. Sellés, A. Vázquez de Miguel, Inorg. Chim. Acta 273 (1998) 270. (b) M.L.H. Green, J.D. Hubert, P. Mountford, J. Chem. Soc. Dalton Trans. (1990) 3793. (c) A.H. Liu, R.C. Murray, J.C. Dewan, B.D. Santarsiero, R.R. Schrock, J. Am. Chem. Soc. 109 (1987) 4282. (d) R.C. Murray, L. Blum, A.H. Liu, R.R. Schrock, Organometallics 4 (1985) 953.

[13] (a) N. Walker, D. Stuart, Acta Crystallogr. A 39 (1983) 158. (b) F. Ugozzoli, Comput. Chem. 11 (1987) 109.

[14] G.M. Sheldrick, Acta Crystallogr. A 46 (1990) 467.

[15] G.M. Sheldrick, SHELXL 93, University of Gottingen, Göttingen, Germany, 1993.

[16] G.M. Sheldrck, SHELXs-86 Program for the Solution of Crystal Structures, Universität Göttingen, Göttingen, Germany, 1986.

[17] G.M. Sheldrick, SHELX-76 Program for Crystal Structure Determination, Cambridge, University of Cambridge, 1976. 